\title{
Ergonomic analysis through good manufacturing practice (gmp) training (case: Binjai MSME)
}

\author{
Listiani Nurul Huda ${ }^{1 *}$, and Rifqi Athaullah ${ }^{1}$ \\ ${ }^{1}$ Department of Industrial Engineering, Universitas Sumatera Utara, 20154, Medan, North \\ Sumatera, Indonesia.
}

\begin{abstract}
The work environment is one of the most important factors in production. In this paper, a study was conducted on the work environment in MSMEs to determine the safety and health of the work environment in producing products. Specifically, the study was conducted to see the deviation in the application of GMP in MSME. The subjects were 30 MSMEs involved in the research from Binjai Municipalities. This study uses a qualitative analysis method that aims to evaluate the level of application of 14 aspects of GMP and find out the understanding of MSMEs on aspects of GMP. The analysis results show that the types of products with the most considerable deviations from the GMP aspect are Bakery Products and Ready-to-Eat Snacks MSMEs. However, overall, the most urgent aspects to improve are Aspect Process control and Production Location and Environment. The deviation results can reach $100 \%$, indicating that GMP implementation is lacking or does not apply GMP.
\end{abstract}

\section{Introduction}

The work environment of an industry, such as room ventilation, room temperature, room humidity, and lighting, must meet the health requirements of the work environment so as not to cause health complaints both for workers and for food products produced [1]. The quality of a healthy environment in terms of physical, chemical, biological and social aspects is related to the industry as a place for production to take place [2]. As for environmental health requirements, including water media, soil media, food media, facilities and buildings, vectors, and disease-carrying animals [3] must comply with the proper guidelines. Food industry level (MSME) Micro, Small and Medium Enterprises is an important and strategic part in realizing national food security. Therefore, the work environment's hygiene and health standards is an obligation that must be fulfilled because one of the elements to achieve food security is food quality and food safety [4]. Because in addition to the taste of food products, consumers still need the health and safety aspects of these food products [5]. The Food and Drug Supervisory Agency stated that so far, there have been four main problems of food safety, namely (1) food contamination by microbes due to poor sanitation and hygiene practices in the production environment, and (2) food

*Corresponding author: listiani@usu.ac.id 
contamination by hazardous chemicals such as pesticide residues, drug residues. Animals, heavy metals, mycotoxins and so on, (3) the wrong use of hazardous materials that are prohibited from being used for food such as formalin, borax, and rhodamine B.

Therefore, food safety must be the primary concern of various business actors engaged in the food industry. In addition, food safety is a form of effort to prevent and avoid the emergence of diseases in the human body as consumers / foodborne illness [7]. Some standards and rules are used as references in food safety, one of which is the application of Good Manufacturing Practices (GMP).

Good Manufacturing Practices(GMP) is defined as a rule in producing or processing good products. This rule includes provisions/instructions/procedures covering the location, building, room and infrastructure of the factory or production site, processing stage, processing equipment, storage and distribution of products, level of cleanliness and workforce health, and waste management and environmental management [8]. This study evaluates the work environment based on the GMP Assessment (GMP Internal Audit) to see the level of application of GMP to MSMEs and determine MSME's understanding of GMP aspects.

\section{Methodology}

\subsection{Time and Research Subject}

This research was conducted in June 2021 at Saka Hotel, Medan. The subjects in this study were all participants of the Good Manufacturing Practice (GMP) training at the of Binjai municipality. This training was organized by the Ministry of Cooperatives and MSMEs in collaboration with the Department of Industry and Trade of the Provincial Governments of North Sumatera. There are 30 MSME participants who are the subjects of this study.

\subsection{Research Instruments}

The instrument used in this study was a questionnaire. The questionnaire used is the Internal Audit GMP which consists of 14 aspects of the assessment aimed at measuring the level of application of GMP in each MSME owned by the respondents. Filling out the questionnaire was done using online media, namely the Google Form platform. The following are 14 aspects of the GMP Internal Audit assessment, which are indicators of the level of GMP implementation in an MSME, which can be seen in Table 1. 
Table 1. Aspects of Internal Audit Assessment

\begin{tabular}{|c|l|}
\hline No & \multicolumn{1}{|c|}{ Aspects of assessment } \\
\hline 1. & Production Location and Environment \\
\hline 2. & Buildings and facilities \\
\hline 3. & Production Equipment \\
\hline 4. & Water supply or water supply facilities \\
\hline 5. & Hygiene and sanitation facilities and activities \\
\hline 6. & Employee health and hygiene \\
\hline 7. & $\begin{array}{l}\text { Employee hygiene and sanitation program } \\
\text { maintenance }\end{array}$ \\
\hline 8. & Storage \\
\hline 9. & Process control \\
\hline 10. & Food labelling \\
\hline 11. & Supervision by the person in charge \\
\hline 12. & Product recall \\
\hline 13. & Recording and documentation \\
\hline 14. & Employee training \\
\hline
\end{tabular}

\subsection{Research Procedure}

This study uses a descriptive method that seeks to describe the situation comprehensively in a real context related to the condition of MSMEs and the MSME's knowledge of GMP. In the analysis phase, descriptive statistical methods are used; namely, statistics used to analyze data by describing or describing the data that has been collected as it is without intending to make conclusions that apply to the public or generalizations. Thus, this analysis is only in the form of accumulation of basic data in the form of mere descriptions in the sense of not seeking or explaining interrelationships, testing hypotheses, making predictions, or drawing conclusions.

In this study, the GMP self-assessment questionnaire was given to the trainees. The questionnaire results were then grouped into categories based on the standards of the Indonesian Food and Drug Supervisory Agency (BPOM) for each region. Then participants will be given a GMP self-assessment sheet as material for the internal audit of their respective businesses. Finally, this assessment will be analyzed to obtain GMP counselling actions that are in accordance with the current level of application in MSMEs.

\section{Results}

\subsection{Respondent Category Results}

The first procedure after distributing the questionnaires is the grouping of respondents. All MSMEs that are respondents are food businesses, so they are grouped by food category according to their products. The grouping of MSMEs in Binjai Municipality can be seen in Table 2 .

Table 2. Grouping of SMEs in Binjai Municipality

\begin{tabular}{clc}
\hline $\begin{array}{c}\text { Food } \\
\text { Category }\end{array}$ & \multicolumn{1}{c}{ Information } & Number of MSMEs \\
\hline 04 & $\begin{array}{l}\text { Fruits and Vegetables, including } \\
\text { Nuts. }\end{array}$ & 4
\end{tabular}




\begin{tabular}{clc}
07 & Bakery Products & 4 \\
10 & Eggs and Egg Products & 1 \\
14 & Beverages, excluding Dairy & 2 \\
15 & Products & 7 \\
16 & Ready-to-Eat Snacks & 12 \\
\hline \multicolumn{2}{c}{ Ready-to-Eat Food (Packaged) } & 30 \\
\hline
\end{tabular}

Table 3 is obtained from the results of the types of businesses of Binjai MSMEs who register and attend GMP training. Based on the table, it can be seen that most respondents in Binjai Municipality are MSMEs with Ready-to-eat (packaged) food products, namely Food consisting of food products from Food Categories 04, 07, 10, 14, 15, and 16. This category is obtained based on Standards of the Food and Drug Supervisory Agency Number 34 of 2019 concerning Food Categories. Therefore, MSMEs from Binjai is dominated by Ready-to-eat food products such as fried rice, uduk rice, fried vermicelli, soto, burgers, and pecel.

\subsection{GMP Self-Assessment Analysis}

\subsubsection{Deviations by food category}

The results of the GMP Internal Audit of each MSME carried out by each respondent (self assessment) on the condition of their MSMEs obtained some deviations that occurred in these MSMEs, then grouped MSMEs that made the same deviation from each of the 14 aspects of GMP. As a result, deviations from the GMP aspect of MSMEs based on food categories in Binjai Municipality can be seen in Table 3.

Table 3. Binjai Municipal MSME GMP deviations; sorted from Highest to Lowest Deviation

\begin{tabular}{|c|c|c|c|c|c|c|c|}
\hline \multirow[b]{2}{*}{$\begin{array}{c}\text { GMP } \\
\text { Aspect }\end{array}$} & \multicolumn{6}{|c|}{ Food Category } & \multirow[b]{2}{*}{$\begin{array}{c}\text { Ave } \\
- \\
\text { rage }\end{array}$} \\
\hline & $\begin{array}{c}\text { Fruits and } \\
\text { Vegetable } \\
\text { s, Whole } \\
\text { Grains }\end{array}$ & $\begin{array}{c}\text { Bakery } \\
\text { Products }\end{array}$ & $\begin{array}{c}\text { Beverages, } \\
\text { Excluding } \\
\text { Dairy } \\
\text { Products }\end{array}$ & $\begin{array}{l}\text { Eggs and } \\
\text { Egg } \\
\text { Products }\end{array}$ & $\begin{array}{c}\text { Ready- } \\
\text { to-Eat } \\
\text { Snacks }\end{array}$ & $\begin{array}{c}\text { Ready-to- } \\
\text { Eat Food } \\
\text { (Packaged } \\
\text { ) }\end{array}$ & \\
\hline 12 & $0 \%$ & $50 \%$ & $100 \%$ & $0 \%$ & $29 \%$ & $42 \%$ & $37 \%$ \\
\hline 1 & $0 \%$ & $50 \%$ & $0 \%$ & $50 \%$ & $43 \%$ & $33 \%$ & $29 \%$ \\
\hline 11 & $0 \%$ & $50 \%$ & $50 \%$ & $0 \%$ & $29 \%$ & $17 \%$ & $24 \%$ \\
\hline 4 & $0 \%$ & $25 \%$ & $0 \%$ & $50 \%$ & $21 \%$ & $8 \%$ & $17 \%$ \\
\hline 14 & $0 \%$ & $25 \%$ & $0 \%$ & $0 \%$ & $43 \%$ & $17 \%$ & $14 \%$ \\
\hline 3 & $8 \%$ & $8 \%$ & $33 \%$ & $0 \%$ & $19 \%$ & $11 \%$ & $13 \%$ \\
\hline 13 & $0 \%$ & $13 \%$ & $0 \%$ & $25 \%$ & $14 \%$ & $17 \%$ & $11 \%$ \\
\hline 7 & $6 \%$ & $13 \%$ & $25 \%$ & $13 \%$ & $4 \%$ & $8 \%$ & $11 \%$ \\
\hline 6 & $10 \%$ & $10 \%$ & $20 \%$ & $0 \%$ & $11 \%$ & $7 \%$ & $10 \%$ \\
\hline 10 & $50 \%$ & $0 \%$ & $0 \%$ & $0 \%$ & $0 \%$ & $4 \%$ & $9 \%$ \\
\hline 9 & $0 \%$ & $15 \%$ & $0 \%$ & $10 \%$ & $9 \%$ & $3 \%$ & $6 \%$ \\
\hline 5 & $6 \%$ & $13 \%$ & $0 \%$ & $0 \%$ & $11 \%$ & $2 \%$ & $5 \%$ \\
\hline 2 & $25 \%$ & $0 \%$ & $0 \%$ & $0 \%$ & $0 \%$ & $6 \%$ & $5 \%$ \\
\hline 8 & $0 \%$ & $0 \%$ & $0 \%$ & $0 \%$ & $0 \%$ & $0 \%$ & $0 \%$ \\
\hline Average & $8 \%$ & $19 \%$ & $16 \%$ & $11 \%$ & $17 \%$ & $12 \%$ & $14 \%$ \\
\hline
\end{tabular}

Note: GMP Aspect can be seen in Table 2.

Based on Table 4, it can be seen the percentage level of deviation in the GMP aspect carried out by MSMEs based on the type of product produced. Judging from the three 
biggest deviations are 12, 1, and 11, which are aspects of Product Withdrawal, Production Location and Environment, and Supervision by the Person in Charge. In contrast, the aspects with the lowest deviations are aspects 8, 2, 5, and 9. These aspects are Storage, Building and Facilities, Hygiene and Sanity Facilities and Activities, and Process Control.

Deviations in the Product Withdrawal aspect occur because MSMEs do not withdraw unsafe food products. These problems are related to the sorting or control of product quality that is not well regulated. Meanwhile, deviations from the Location and Production Environment aspects indicate a work environment that is not maintained, dirty, and dusty. Finally, deviations in the aspect of Supervision by the Person in Charge indicate that MSMEs do not have a Food Safety Extension Certificate (PKP) and internal supervision. The PKP certificate guarantees that the food products produced by the certificate holder have followed the protocols and standards of health and food safety. Procurement of this certification is indeed quite challenging because the certification involves a third party that requires extra preparation from the MSME owners.

Overall, the deviations carried out by the Binjai MSMEs are low because 10 of the 14 aspects studied have deviation values below 15\%. This result shows that Binjai SMEs already have the knowledge and apply GMP practices to their business.

In particular, MSME products Bakery Products and Snackshad the worst deviation values (19\% and 17\%). This result shows that the application of GMP to MSMEs still needs improvement. In MSMEs of Bakery Products, the most urgent aspects to be improved are aspects $12(50 \%), 1(50 \%)$, and $11(50 \%)$. However, for the Ready-to-eat Snacks product have the highest deviations at 1 (43\%), $14(43 \%), 12(29 \%)$, and $11(29 \%)$.

\subsubsection{GMP Aspects Deviations by non-category}

After knowing the tendency of deviation for categories, analysis is carried out for noncategories. The comparison of deviations that occur between MSMEs in Binjai Municipality as a whole is shown in Figure 1.

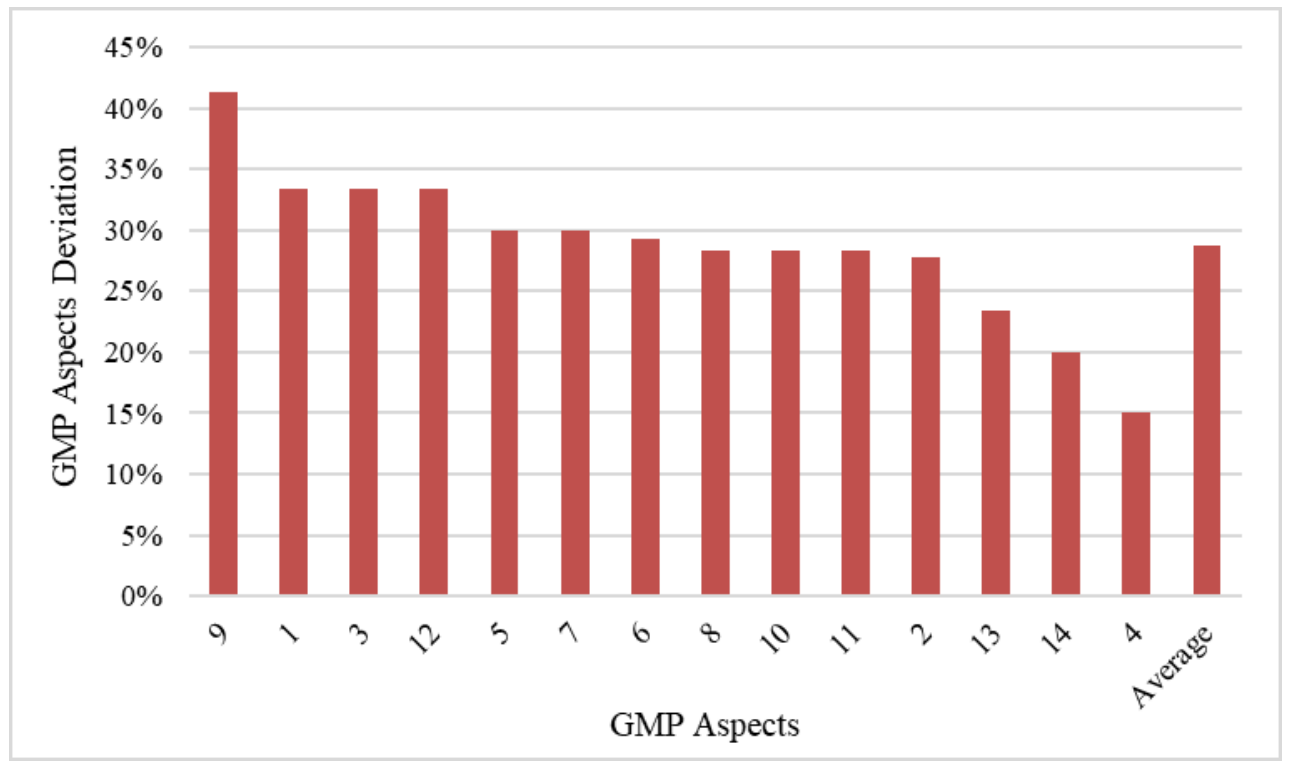

Note: GMP Aspect can be seen in Table 2.

Fig. 1. Number of MSMEs that Deviate from GMP Aspects in Binjai Municipality 
In contrast to Tables 4 and 5, Figure 1 shows the average GMP deviation as a whole and is not grouped by category. Figure 1 shows that the highest deviation values for Binjai Municipality are in aspects $9,1,3$, and 12 with an average value of $41 \%, 33 \%, 33 \%$ and $33 \%$, respectively. These aspects are Process Control, Production Location and Environment, Production Equipment, and Product Withdrawal. While accordng to the average of all aspects, the deviation reach up to $29 \%$.

Based on Figure 1, it can be seen that the deviation in Binjai Municipality has differences for categorical and non-category deviations. In deviations by category, the highest deviation is aspect 12 (Product Withdrawal), aspect 1 (Location and Production Environment), and aspect 11 (Supervision by Person in Charge), while based on noncategory, the highest deviation is aspect 9 (Process Control), Aspect 1 (Location and Production Environment), aspect 3 (Production Equipment), and aspect 12 (Product Withdrawal). Aspects of Process Control relate to the use of raw materials that are not in accordance with the terms of use. There is no production flow chart, BTP is not marked correctly, and measuring tools are not available or not accurate. Aspect of Product Withdrawal refers to the procedure to withdraw the unsafe food in the production facility.

The differemce of average also found between deviations based on food categories $(14 \%)$ and non-category $(29 \%)$. The difference in categories and non-categories is due to differences in the calculation stages between the category and non-category averages. However, both can be used as needed.

\section{Discussion}

Based on the analysis results for the Municipality of Binjai, the most urgent aspects to be improved are aspects of Product Withdrawal, Location and Production Environment, and Supervision by the Person in Charge. Meanwhile, the most urgent product category is Ready-to-eat Snacks and Bakery. Therefore, it is recommended that GMP training focuses on introducing GMP materials for these aspects and pays more attention to understanding the types of MSMEs mentioned. This recommendation applies if GMP outreach is to be coordinated separately for each category. However, suppose the coordination is carried out simultaneously where both regions are coordinated under one roof. In that case, it is recommended to use aspects 9, 1, 3, and 12 namely Process Control, Production Location and Environment, Production Equipment, and Product Withdrawal as priorities because they are the highest average deviations for non-categories.

Both deviations has the same aspect on Aspect Process control and Production Location and Environment. This finding shows that these aspects is crucial and the hardest to fulfill. Most MSMEs do not even know the good standard to reach lower deviation. These aspects are related to ergonomic environmental of the production plant.

Employees are still exposed to the risk of non-ergonomic working conditions. At the same time, a good work environment can increase employee productivity [10 \& 11]. The food products produced also do not meet the hygiene standards for food, which will pose a risk to the health of consumers. So far, consumers have not considered this condition as a severe problem. However, along with increasing public awareness of health, improvements must be made, especially if these food products want to be exported abroad. GMP standards in product processing will assist the company's legitimacy in competing with similar products internationally.

Based on the most common deviation aspects found from category and non-category, it can be concluded that Binjai MSMEs need adjustments to tidy up the work environment, record and document, assign responsible persons, train employees, make food labels, and control processes. An ergonomic approach that can be taken to overcome these aspects is the use of 5S. 5S methods include Seiri (Sort), Seiton (Set in Order), Seiso (Clean), 
Seiketsu (systematize), and Shitsuke (Standardize) [12]. This method is simple and can be applied to businesses of any technological level. In addition, this application also saves workspace, can increase productivity, and most importantly, requires little cost [13].

Furthermore, the $5 \mathrm{~S}$ method can build a work environment and system by identifying and standardizing the system. This environment includes workers, machines, and methods in MSMEs. Thus, before the field review is carried out, MSMEs can build a standard work environment that can be further improved by implementing GMP.

In order to improve the conditions for implementing GMP, it requires initiative and capital from business actors. However, in general, business actors are reluctant to make repairs that are considered troublesome and require money. Therefore, support from third parties is needed to facilitate and provide guidance on the importance and benefits of GMP in the business world. In addition, support from the government and related agencies is needed to make the implementation efforts structured and sustainable.

\section{Conclusion}

Applying GMP to MSMEs in the Municipality of Binjai still does not meet the requirements according to the Good Manufacturing Practice (GMP) guidelines. This is because there are still many deviations from aspects of GMP. The results of the GMP application in the MSMEs in the Municipality of Binjai shows that deviations from aspects of GMP were found in almost all aspects with the highest deviation up to $100 \%$.

Deviations from the application of GMP are in line with the inadequacy of the working environment for MSMEs, the inadequacy of the production process and the lack of knowledge of MSMEs so that food safety to be achieved previously must begin with improving the work environment, production processes and facilities in accordance with Good Manufacturing Practice (GMP) aspects. Therefore, a simple method that can be practised in MSMEs is applying the simple $5 \mathrm{~S}$ method.

\section{References}

1. B. D. A Puspo, S. Sulistiyani, B. Budiyono. J.K.M. 4 (2016)

2. Peraturan Pemerintah RI. Undang-Undang Nomor 66 tahun 2014 tentang Kesehatan Lingkungan (2014)

3. Peraturan Menkes RI. Peraturan Menteri Kesehatan No. 70 tahun 2016 tentang Standar dan Persyaratan Kesehatan Lingkungan Kerja Industri (2016)

4. N. Pribadi. Program Ketahanan Pangan: Konsep dan Implementasinya. Makalah disampaikan pada Penyusunan Indikator Kinerja Program Ketahanan Pangan di Bappenas, (2005)

5. P. Hariyadi, Peran Keamanan Pangan Produk Unggulan Daerah dalam Menunjang Ketahanan Pangan dan Menekan Laju Inflasi (2010)

6. Badan Pengawas Obat dan Makanan. Cara Produksi Pangan Yang Baik Untuk Industri Rumah Tangga. Peraturan Kepala BPOM Nomor HK.03.1.23.04.12.2206. Jakarta (2012)

7. H. Thaheer, Sistem manajemen HACCP (Hazard analysis critical control points). (Bumi Aksara, Jakarta, 2005)

8. Direktorat P2HP. Cara Pengolahan yang Baik (Good Manufacturing Practices) Komoditas Hortikultura. Direktorat Jenderal Bina Pengolahan dan Pemasaran Hasil Pertanian. (2004) 
9. Kementerian Perindustrian Republik Indonesia. Peraturan Menteri Perindustrian Republik Indonesia Nomor 75/M-IND/PER/7 tahun 2010 tentang Pedoman Cara Produksi Pangan Olahan yang Baik (Good Manufacturing Practice). Jakarta, (2010)

10. W. Jaskiewicz, K. Tulenko. Hum. Resour. Health. 10, 38 (2012).

11. L. N. Huda. Adv. in. Health. Sci. Res. 1 (2017).

12. M. Sultana, N. Zaman. J. of. The. Cost. And. Manag. 47(5) (2019).

13. Sk. Riad Bin Ashraf, Md. Mynur Rashid, and Dr. A R M Harunur Rashid. Inter. Res. J. of. Eng. And. Tech. (IRJET). 04 (2017) 